\title{
Evaluation of Plant Densities and Various Irrigation Regimes of Sorghum (Sorghum bicolor L.) under Low Water Supply
}

\author{
Ali A. Alderfasi ${ }^{*}$, Mostafa M. Selim1, Bushra A. Alhammad² \\ ${ }^{1}$ Department of Plant Production, Faculty of Food and Agriculture Science, King Saud University, Riyadh, Saudi \\ Arabia \\ ${ }^{2}$ Faculty of Sciences and Humanities, Salman Bin Abdulaziz University, Alkharj, Saudi Arabia \\ Email: *aderfasi@gmail.com
}

Received 9 November 2015; accepted 8 January 2016; published 11 January 2016

Copyright (C) 2016 by authors and Scientific Research Publishing Inc.

This work is licensed under the Creative Commons Attribution International License (CC BY). http://creativecommons.org/licenses/by/4.0/

(c) (i) Open Access

\begin{abstract}
Drought stress, during growth season along with plant density, is an important problem that needs attention. In order to investigate the influence of both factors in increasing the water use efficiency, field experiments were laid out in split-plot design at Agriculture Research Station, Collage of Food and Agriculture Sciences, King Saud University, to investigate the effects of irrigation intervals viz., irrigation every (6, 9 and 12 days) under different plant densities i.e., $(6,8$ and 10 plants $/ \mathrm{m}^{2}$ ) on growth, yield and yield component parameters as well as grain quality of sorghum local variety (Gizani). Results revealed that almost all growth, yield and yield component parameters were significantly influenced by both factors as well as their interaction. Chemical composition of seeds, leaf proline content and WUE were also considered. Severe drought stress condition caused gradual decrease in most of the growth characters as compared to watered treatment and reflected in decreasing yield and yield component characters. Increasing plant densities led to raise biomass production and seed yield per unit area and not able to compensated the low number and weight of grains per panicle. Contrary, low plant density, under adequate irrigation conditions, can be compensated by a high number of grains per panicle and high weight of the grain. Maximum seed yield per hectare was recorded by the interactional effects of most watered treatments (irrigation every 6 days) and plant density of 10 plants per square meter.
\end{abstract}

\section{Keywords}

Sorghum, Plant Density, Plant Population, Irrigation, Water Use Efficiency, Drought Stress

\footnotetext{
"Corresponding author.

How to cite this paper: Alderfasi, A.A., Selim, M.M. and Alhammad, B.A. (2016) Evaluation of Plant Densities and Various Irrigation Regimes of Sorghum (Sorghum bicolor L.) under Low Water Supply. Journal of Water Resource and Protection, 8 , 1-11. http://dx.doi.org/10.4236/jwarp.2016.81001
} 


\section{Introduction}

Human demand for food increases with increasing world population. It is expected that human population will increase to over 8 billion by the year 2020 and this will worsen the current scenario of food security. It is predicted that at least 10 million people will be hungry and malnourished in the world by the end of this century [1] Thus, in order to feed the world's population agricultural production must be doubled, produced in more environmentally sustainable ways and more profitable crops with shorter growing period should be used [2].

The picture is more aggravate under arid and semiarid regions, with the fact that over a quarter of land area on the earth is considered as arid and semiarid regions [3]. In these regions, water deficit is the main factor that limits crops performance. Limitation of water source, irregular annual rainfall during growth season and lack of sources management cause severe decreasing in crops yield [4]. Therefore, drought stress during growth season is an important problem that needs to attention [5]. Sorghum (Sorghum bicolor (L.) Moench) is known to be relatively more tolerant to drought conditions than other crops [6]. The resistance of sorghum to harsh climatic conditions ranked it to the fifth important cereal crop in the world [7] [8]. Therefore, it is fair to assume that sorghum has a great potential for arid areas. Sorghum plays an important role as a staple food grain in many developing countries [9]. Drought stress occurrence and intensity affect characteristics like plant height, plant dry weight, specific leaf area, seed yield and yield components [10]. Thus, the effect of water stress on plants under water deficit conditions in the soil could be determined from smaller sizes of leaf or low heights in plants or decreased wet or dry weight as well as lower yield and yield components [11]. The severity of loss depends on many factors viz., timing, length and severity of the drought period.

Plant density is the second important factor in crop yield. The use of proper planting density of sorghum crop plays an important role in the efficient use of water irrigation applied and reaches to optimum yield performance. The relationship between plant density and yield of cereals has been studied extensively, but conflicting reports have led to a renewed interest in the effects of high plant densities on yield of cereals. [12] [13] reported that increasing plant density up to 166 and 333 thousand plants per hectare for tall and short types of sorghum respectively decreased plant height, stem diameter, number of green leaves and leaf area per plant, while grain yield for both types increased by increasing plant density. Some researchers were recorded the highest dry matter production at high plant densities [14] [15]. While others expressed that a greater number of grains per panicle and higher weight of grains compensated the lower plant densities [16]. [17] reported that plant density affectd the post-flowering source/sink ratio through its effects on plant leaf area, the amount of light intercepted per plant and kernel number per plant. Recent research reports of [18] showed a 4\% increase in yield for corn grown in 76-cm row spacing compared with 56-cm row spacing. [19] found that, the proper plant density is the best way for improving sorghum production under arid condition. Although there are a huge number of research reports, there is not accurate information of the appropriate plant density and irrigation schedules that can follow by farmers for maximum yield performance. Therefore, the present investigation was focused on evaluation of sorghum responses to plant densities and irrigation schedules on growth, grain yield and yield component characters as well as grain chemical constituents of sorghum under drought stress conditions.

\section{Material and Methods}

\subsection{Experimental Design, Field Site Description and Plant Material}

Factorial experiments based on split-plot design with four replications were done in two successive summer seasons of 2011 and 2012 to evaluate growth, yield and yield components parameters of local sorghum variety (Gizani) under three irrigation intervals viz., every (6, 9 and 12 days) were assigned in main plots and three plant densities i.e., (6, 8 and 10 plants/ $\mathrm{m}^{2}$ achieve by plants spaced 30, 25 and $20 \mathrm{~cm}$ ) were randomly distributed in sub-plots at Agriculture Research Station, Collage of Food and Agriculture Sciences, King Saud University, Deerab, South Riyadh region, Saudi Arabia (24.42 $\mathrm{N}$ latitude and $46.44^{\circ} \mathrm{E}$ longitudes, Altitude $\left.600 \mathrm{~m}\right)$. The region is under arid climate conditions, with high temperatures and truncated rainfall during the summer and low temperatures and little rainfall during the winter season. Maximum and minimum mean temperature and relative humidity during the two growing seasons are presented in (Table 1).

\subsection{Soil and Irrigation Water Characters}

Prior to the field experiment, the field soil site was sampled $0-60 \mathrm{~cm}$ depth from five sites for physical and chemical analyses according to the methods described by [20] and [21], results are shown in (Table 2 and Table 
3). Chemical properties of the irrigation water used were also analyzed according to the methods described by American Public Health Association, [22], results are presented in (Table 4). Total number of irrigation and amount of water used for each treatment over the growing seasons are mentioned in (Table 5).

\subsection{Field Preparation and Sowing}

Seed bed was prepared before sowing as recommended; field was ploughed three cross harrowing's with tractor followed by a thorough harrowing to break the clods. Phosphorus fertilizer was applied at the rate of $70 \mathrm{~kg}$. $\mathrm{P}_{2} \mathrm{O}_{5}$ /ha. as the form of superphosphate $\left(16 \% \mathrm{P}_{2} \mathrm{O}_{5}\right)$, whereas potassium as the form of potassium sulphate (42\% $\mathrm{K}_{2} \mathrm{O}$ ), by the rate of $100 \mathrm{~kg} \mathrm{~K}_{2} \mathrm{O}$ was applied broadcasting during soil preparation, the field was properly leveled

Table 1. Monthly maximum, minimum, mean temperature and relative humidity during 2011 and 2012 seasons.

\begin{tabular}{|c|c|c|c|c|c|c|c|c|}
\hline \multirow{3}{*}{ Month } & \multicolumn{6}{|c|}{ Temperature $\left({ }^{\circ} \mathrm{C}\right)$} & \multirow{2}{*}{\multicolumn{2}{|c|}{ Relative humidity (\%) }} \\
\hline & \multicolumn{2}{|c|}{ Maximum } & \multicolumn{2}{|c|}{ Minimum } & \multicolumn{2}{|c|}{ Mean } & & \\
\hline & 2011 & 2012 & 2011 & 2012 & 2011 & 2012 & 2011 & 2012 \\
\hline May & 40.2 & 41.5 & 22.9 & 23.4 & 31.6 & 32.5 & 10.6 & 10.4 \\
\hline June & 42.7 & 44.4 & 24.8 & 25.9 & 33.8 & 35.2 & 10.2 & 10.3 \\
\hline July & 44.9 & 45.7 & 26.7 & 27.3 & 35.8 & 36.5 & 12.7 & 10.4 \\
\hline August & 44.9 & 45.9 & 27.8 & 26.9 & 36.4 & 36.4 & 10.9 & 10.8 \\
\hline September & 41.8 & 42.7 & 24.4 & 23.3 & 33.1 & 33.3 & 11.2 & 11.4 \\
\hline October & 37.2 & 38.2 & 19.4 & 18.5 & 28.3 & 33.3 & 11.3 & 11.6 \\
\hline
\end{tabular}

Table 2. Physical analyzes of the experimental soil site during the two growing seasons.

\begin{tabular}{ccccccccccccc}
\hline $\begin{array}{c}\text { Properties } \\
\text { season }\end{array}$ & $\begin{array}{c}\text { Saturation } \\
\%\end{array}$ & $\begin{array}{c}\mathrm{pH} \text { soil } \\
\text { paste }(1: 5)\end{array}$ & $\begin{array}{c}\mathrm{EC} \\
(\mathrm{dS} / \mathrm{m})\end{array}$ & $\begin{array}{c}\mathrm{O} . \mathrm{M} \\
\%\end{array}$ & $\begin{array}{c}\mathrm{CaCO}_{3} \\
\%\end{array}$ & $\begin{array}{c}\text { Field } \\
\text { capacity }(\%)\end{array}$ & $\begin{array}{c}\text { Wilting point } \\
(\%)\end{array}$ & $\begin{array}{c}\text { Sand } \\
(\%)\end{array}$ & $\begin{array}{c}\text { Silt } \\
(\%)\end{array}$ & $\begin{array}{c}\text { Clay } \\
(\%)\end{array}$ & $\begin{array}{c}\text { Soil texture } \\
(\%)\end{array}$ \\
\hline First season & 29.70 & 7.86 & 3.88 & 0.46 & 29.42 & 16.30 & 7.67 & 57.92 & 27.20 & 14.88 & Sandy loam \\
\multirow{2}{*}{ Second season } & 28.12 & 7.81 & 3.91 & 0.47 & 29.63 & 16.42 & 7.71 & 57.82 & 27.25 & 14.90 & Sandy loam \\
\hline
\end{tabular}

Table 3. Chemical analyzes of the experimental soil site during the two growing seasons.

\begin{tabular}{ccccccccc}
\hline \multirow{2}{*}{$\begin{array}{c}\text { Properties } \\
\text { season }\end{array}$} & \multicolumn{9}{c}{ Available macro and micro nutrients (ppm) } \\
\cline { 2 - 8 } & $\mathrm{N}$ & $\mathrm{P}$ & $\mathrm{K}$ & $\mathrm{Fe}$ & $\mathrm{Mn}$ & $\mathrm{Zn}$ & $\mathrm{Cu}$ \\
\hline First season & 35.40 & 14.80 & 243.50 & 3.27 & 2.44 & 6.07 & 0.70 \\
Second season & 35.80 & 12.76 & 251.42 & 3.24 & 2.61 & 6.13 & 0.74 \\
\hline
\end{tabular}

Table 4. Chemical analyzes of the irrigation water during the two growing seasons.

\begin{tabular}{|c|c|c|c|c|c|c|c|c|c|c|c|c|c|}
\hline \multirow{2}{*}{$\begin{array}{l}\text { Properties } \\
\text { season }\end{array}$} & \multirow{2}{*}{$\mathrm{pH}$} & \multirow{2}{*}{$\begin{array}{c}\mathrm{EC} \\
(\mathrm{dS} / \mathrm{m})\end{array}$} & \multirow{2}{*}{$\begin{array}{c}\text { O.M } \\
\%\end{array}$} & \multicolumn{4}{|c|}{ Soluble cations (meq./L) } & \multicolumn{3}{|c|}{ Soluble anions (meq/L) } & \multicolumn{3}{|c|}{ Total NPK (ppm) } \\
\hline & & & & $\mathrm{Ca}^{+}$ & $\mathrm{Mg}^{+}$ & $\mathrm{Na}^{+}$ & $\mathrm{K}^{+}$ & $\mathrm{HCO}_{3}^{-}$ & $\mathrm{Cl}^{-}$ & $\mathrm{SO}_{3}^{-}$ & $\mathrm{N}$ & $\mathrm{P}$ & $\mathrm{K}$ \\
\hline First season & 7.10 & 1.45 & 0.02 & 6.30 & 1.75 & 7.35 & 0.44 & 2.40 & 4.85 & 9.14 & 10.50 & 9.23 & 17.00 \\
\hline Second season & 7.17 & 1.73 & 0.02 & 5.50 & 1.87 & 7.65 & 0.46 & 2.60 & 4.80 & 8.56 & 11.01 & 9.42 & 17.12 \\
\hline
\end{tabular}

Table 5. Total number of irrigation and amount of water used for each treatment over the growing season in both seasons.

\begin{tabular}{ccccc}
\hline \multirow{2}{*}{ Water regime treatments } & \multicolumn{2}{c}{ Mean water apply $\left(\mathrm{m}^{3} / \mathrm{ha}\right)$} & \multicolumn{2}{c}{ Number of irrigations over growing season } \\
\cline { 2 - 4 } & First season & Second season & First season \\
\hline Weekly irrigation & 10,000 & 10,050 & 20 \\
Irrigation every 9 days & 7000 & 7000 & 14 & 10 \\
Irrigation every 12 days & 5000 & 5000 & 14 \\
\hline
\end{tabular}


and divided into plots each one $(3 \times 3.5 \mathrm{~m})$ included six ridges, three meters long and $50 \mathrm{~cm}$ apart, total experimental unit area was $10.5 \mathrm{~m}^{2}$ earmarked with raised bunds all around to minimize the movement of water. Pipe type was laid to facilitate irrigation to plots individually (irrigation network).Sowing was done on $14^{\text {th }}$ and $16^{\text {th }}$ April in the first and second seasons, respectively. Plants were thinned according to plant densities 20 days after sowing. Nitrogen fertilizer was applied by the recommended dose of $\mathrm{N}$ (100 Kg N/ha.) two times, once after thinning and the second 45 days later. Water irrigation applied according to the experimental treatments by using flowed irrigation system, through line pipe provide with meter gages for measuring water applied over the growing season.

\subsection{Treatments Details}

Nine treatments were investigated in the study in a split-plot design arrangement in randomized complete block design with irrigation treatments (every 6, 9 and 12 days) as the main plot, and plant density (6, 8 and 10 plants $/ \mathrm{m}^{2}$ ) as the sub-plot in three replications.

\subsection{Measurement of Plant Parameters}

During growth stages number of days to $50 \%$ of flowering was determined. After 80 days from sowing a plant sample of 10 plants was taken for studying some growth parameters viz., plant height $(\mathrm{cm})$, stem diameter $(\mathrm{cm})$, number of green leaves per plant and leaf area $\left(\mathrm{cm}^{2}\right)$ of the second upper leaf using the following formula: Leaf area $\left(\mathrm{cm}^{2}\right)=$ leaf length $(\mathrm{cm}) \times$ maximum leaf width $(\mathrm{cm}) \times 0.747$.

\subsubsection{Harvesting, Measuring Yield and Yield Component Characters}

At harvest, two central rows of each sub-plot were hand pulled and completely air dried and threshed, then seed yield per hectare as well as biological yield per hectare were determined. Sub sample of ten plants was taken for determining yield component characters viz., head Length, cm; head weight, gm; grain weight per head gm; total plant weight kg, 1000 seed and grain yield per unit area.

\subsubsection{Calculation Yield Parameters}

\section{1) Irrigation water-use efficiency}

Irrigation water use efficiency (IWUE) $\mathrm{kg} / \mathrm{m}^{3}$ is defined as the ratio of the crop yield (final economic yield) to irrigation water applied over the growing season, including rainfall [23] as follows: water use efficiency (WUE) $\left(\mathrm{kg} / \mathrm{m}^{3}\right)=$ economical yield in $\mathrm{kg}$ divided by seasonal water used.

2) Harvest and crop index

Harvest index (HI) and crop index (CI) were also calculated using the formula suggested by [24] as follows:

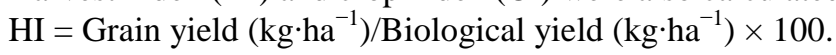

Biological yield $=$ Grain yield + straw yield, CI $=$ Grain yield $\left(\mathrm{kg} \cdot \mathrm{ha}^{-1}\right) /$ Straw yield $\left(\mathrm{kg} \cdot \mathrm{ha}^{-1}\right) \times 100$.

\subsubsection{Chemical Analyses}

\section{1) Proline content}

Leaf proline content was determined in fully expanded uppermost leaves at full flowering stage using the method of [25].

2) Chemical composition of grains

Crude Protein content was estimated by determining nitrogen content in absolutely dry seeds using microkjeldahl method according to the procedures described by [26] and then nitrogen percentage was multiplied by 6.25 and protein yield was calculated.

Total carbohydrates percentage were determined using spectrophotometer and total soluble sugar using soxhelt apparatus by the method described by [27].

\subsection{Statistical Analysis}

The experimental design was laid out in split-plot design with 4 replications according to the methods described by [28]. Main plots were occupied by three water intervals, whereas plant densities were arranged in sub-plots. The data collected during the experiment processes was subjected to analysis of variance according to splitdesign and upon obtaining significant differences, Least Significant Differences (LSD) at $0.05 \%$ of probability 
was calculated and then differences among treatments means were compared.

\section{Results and Discussion}

\subsection{Effect on Growth Characters}

Analysis of variance of the data for growth characters presented in (Table 6) showed that severe drought stress condition caused gradual decrease in most of the growth characters except stem diameter and number of green leaves per plant viz., time required to reach to 50\% flowering, plant height and leaf area per plant. [29] reported that the time of flowering and maturity for the three mungbean cultivars was shortened under stress condition compared to well-watered conditions. Data obtained also reveal that, the most watered treatment, irrigation every 6 days exceeded the other treatments and recorded the highest values of each of growth character in both seasons, whereas the minimum values were obtained in the less irrigated treatment, irrigation every 9 followed by 12 days (Table 6). The contribution of water stress in most of growth characters may be due to the availability of more resources (nutrient + water) generative parts of the plant for receiving to maximum growth rate. These results confirm the finding of [11] who concluded that the effect of water stress on plant growth under water deficit conditions in the soil could be determined from smaller sizes of leaf or low plant heights or decreased fresh or dry weight and later lower yield and yield component characters. In the same concern, [10] reported that drought stress affected on growth characteristics like plant height, plant dry weight and specific leaf area.

The data presented in the same table also evident that increasing plant competition for water and nutrients, which are induced at high plant densities, resulted in decreased the time required to reach to 50\% of flowering, plant height, stem diameter, number of green per plant, and leaf area in both seasons. Similar results were obtained by [13], he found that increasing plant density decreased growth characters of sorghum. [17] reported that plant density affects the source/sink ratio through its effects on plant leaf area. Furthermore, the same trend of

Table 6. Means of growth characters of sorghum under different irrigation intervals and plant densities as well as their interaction in 2011 and 2012 seasons.

\begin{tabular}{|c|c|c|c|c|c|c|c|c|c|c|c|}
\hline \multirow[b]{2}{*}{$\begin{array}{c}\text { Irrigation } \\
\text { intervals } \\
\text { (A) }\end{array}$} & \multirow[b]{2}{*}{$\begin{array}{c}\text { Plant } \\
\text { density, } \mathrm{m}^{2} \\
\text { (B) }\end{array}$} & \multicolumn{5}{|c|}{2011 season } & \multicolumn{5}{|c|}{2012 season } \\
\hline & & $\begin{array}{c}50 \% \\
\text { Flowering }\end{array}$ & $\begin{array}{c}\text { Plant } \\
\text { height } \\
\text { cm }\end{array}$ & $\begin{array}{c}\text { Stem } \\
\text { diameter, } \\
\text { cm }\end{array}$ & $\begin{array}{c}\text { No. of } \\
\text { leaves/ } \\
\text { plant }\end{array}$ & $\begin{array}{l}\text { Leaf area } \\
\mathrm{cm}^{2}\end{array}$ & $\begin{array}{c}50 \% \\
\text { flowering }\end{array}$ & $\begin{array}{c}\text { Plant } \\
\text { height } \\
\text { cm }\end{array}$ & $\begin{array}{c}\text { Stem } \\
\text { diameter cm }\end{array}$ & $\begin{array}{l}\text { No. of } \\
\text { leaves/ } \\
\text { plant }\end{array}$ & $\begin{array}{l}\text { Leaf area } \\
\mathrm{cm}^{2}\end{array}$ \\
\hline \multirow{3}{*}{6} & 6 & 77.0 & 269.5 & 1.4 & 9.7 & 591.7 & 79.0 & 276.5 & 1.4 & 10.0 & 615.4 \\
\hline & 8 & 74.0 & 255.5 & 1.4 & 9.8 & 582.5 & 76.0 & 261.0 & 1.3 & 9.9 & 584.5 \\
\hline & 10 & 72.0 & 237.9 & 1.2 & 8.8 & 563.4 & 73.0 & 243.5 & 1.3 & 8.6 & 584.2 \\
\hline \multicolumn{2}{|c|}{ General mean } & 74.3 & 254.3 & 1.3 & 9.4 & 579.2 & 76.0 & 260.3 & & 9.5 & 594.7 \\
\hline \multirow{3}{*}{9} & 6 & 73.0 & 230.7 & 1.2 & 8.7 & 553.3 & 73.0 & 236.5 & 1.1 & 8.8 & 578.2 \\
\hline & 8 & 72.0 & 222.5 & 1.1 & 8.6 & 546.8 & 73.0 & 225.0 & 1.0 & 8.9 & 554.6 \\
\hline & 10 & 70.0 & 218.8 & 1.0 & 8.8 & 537.4 & 68.0 & 219.7 & 1.1 & 8.9 & 536.2 \\
\hline \multicolumn{2}{|c|}{ General mean } & 71.7 & 224.0 & 1.1 & 8.7 & 545.8 & 71.3 & 227.0 & & 8.9 & 556.3 \\
\hline \multirow{3}{*}{12} & 6 & 70.0 & 226.5 & 1.0 & 8.0 & 542.6 & 70.0 & 223.6 & 0.9 & 7.9 & 534.8 \\
\hline & 8 & 72.0 & 215.8 & 1.0 & 7.8 & 522.7 & 73.0 & 220.5 & 0.9 & 7.8 & 522.7 \\
\hline & 10 & 68.0 & 207.5 & 0.9 & 7.7 & 498.6 & 68.0 & 210.4 & 0.9 & 7.6 & 492.7 \\
\hline \multicolumn{2}{|c|}{ General mean } & 70.0 & 216.6 & 0.97 & 7.8 & 521.3 & 70.3 & 218.2 & & 7.8 & 516.7 \\
\hline \multirow{3}{*}{\multicolumn{2}{|c|}{$\begin{array}{l}\text { General mean of } \\
\text { factor (B) }\end{array}$}} & 73.3 & 242.2 & 1.2 & 8.8 & 562.5 & 74.0 & 252.8 & 1.1 & 8.9 & 576.1 \\
\hline & & 72.7 & 231.3 & 1.2 & 8.7 & 550.7 & 74.0 & 235.5 & 1.1 & 8.9 & 553.9 \\
\hline & & 70.0 & 221.4 & 1.0 & 8.4 & 533.1 & 69.7 & 224.5 & 1.1 & 8.4 & 537.7 \\
\hline \multirow{3}{*}{\multicolumn{2}{|c|}{ LSD }} & 1.4 & 10.16 & ns & 1.2 & 28.4 & 1.0 & 12.4 & ns & 0.82 & 30.7 \\
\hline & & 0.5 & 6.9 & ns & ns & 10.9 & 2.3 & 9.2 & ns & ns & 14.9 \\
\hline & & 1.2 & 5.7 & ns & 1.0 & 4.0 & 1.8 & 7.6 & ns & 0.74 & 18.4 \\
\hline
\end{tabular}


decreasing plant growth with increasing plant densities was also observed by [19]. The interaction of plant densities and variable water supplies are presented in (Table 6), clearly obvious that, a general the highest density suffered a higher water stress than the other densities. Since the higher number of plants per $\mathrm{m}^{2}$ extracted the soil stored water and dissolving nutrients more quickly than the lower densities and then suffering a faster water stress. Data clearly indicate that, sowing sorghum by high plant densities 8 and 10 plants per $\mathrm{m}^{2}$ and irrigation every 9 and 12 days registered low values of growth characters compared to the low plant density and most watered treatment. These results confirm the important role of both factors in the efficient use of inputs used especially at low input conditions. These results are in line with those reported by [9]-[11].

\subsection{Effect on Yield Component Characters}

Yield component characters is a complex trait affected by many factors i.e., nutrients absorption; photosynthesis; management agronomic practices and the mutual effects of genetic constituencies in various environments [30]. Regarding to the effect of various water regime, the data presented in (Table 7(a)) showed that, water stress is seriously damaged almost all the yield component characters as a result of previously effect on growth characters. In general gradual decrease in panicle length, panicle weight, and grain weight per panicle, 1000 grain weight and number of grains per panicle were observed as the time of applied water irrigation increased in both seasons. The maximum mean values of these parameters over the both seasons were obtained with the most watered treatments which irrigated every 6 days with values of 20.7, 101.59, 86.9, 34.15 and 252.12, respectively. Whereas, the minimum mean values were $17.67,83.05,56.79,30.0$ and 185.75 , respectively recorded in the less irrigated treatments, irrigation every 12 days in the both seasons (Table 7(a)). These results are similar to those found by [31] and [32], they reported that an obviously decrease in most of yield component characters of cereal under water deficit conditions. Compatible results were also reported by [33] who found that a water deficit during the flowering stage in sorghum reduced the number of grains per panicle that is partly compensated by an increase in grain weight.

Plant density in this study was categorized in class b (Table 7), results indicated that panicle length, and panicle weight, grain weight per panicle, 1000 grain weight and number of grains per panicle were decreased as plant density increased. These results confirmed the fact that the increasing number of plants per $\mathrm{m}^{2}$, need high amount of nutrients and soil stored water to cover all plants requirements. Consequently large number of plants per unit area suffering a faster water stress, than the other densities. Thus, a low plant density, under adequate irrigation conditions can be compensated the expected low yield by a high panicle weight, large number of grains per panicle and high weight of the grain per panicle [34] and [35]. Comparable results in the review were obtained by [16] [17] and [19]. Regarding levels of plant density, the experiments of [36] and [37] indicated that sorghum has the capacity of compensating some yield component characters under certain limiting conditions, which contribute in an important way to the final yield of the crop. The interaction of water intervals $\times$ plant densities had also a significant effect on panicle length, and panicle weight, grain weight per panicle, 1000 grain weight and number of grains per panicle in both seasons. The maximum value of each parameter was registered when plants were sown by plant density 6 plants per $\mathrm{m}^{2}$ and received irrigation water every 6 days, followed by sowing plants by 8 plants per $\mathrm{m}^{2}$ at the same irrigation level. Results in the same table, also clear that increasing plant densities and time of applied water irrigation induced a decreased in all yield component characters of sorghum. The highest decrement was observed at high plant density ( 10 plants $/ \mathrm{m}^{2}$ and received irrigation water every 12 days). Such results are probably early, since the effect was detected in most of growth characters, which may be due to low availability of water and nutrient and consequently less photosynthesis because of high inter-specific competition and high rate of respiration as a result of enhanced mutual shading [37]. These results confirm the important effect of water stress and plant density as well as their interactions on the yield components of sorghum.

\subsection{Effect on Grain Yield and Yield Parameters}

A general and gradual decrease in grain yield production, biological yield, harvest index and crop index was observed as the time of applied irrigation water in the three sorghum plant densities increased. Thus, the maximum values of all of these parameters were obtained in the most watered treatments, generally in treatment irrigated every 6 days and the minimum values in the less irrigated treatments, which irrigation was located every 9 and 12 days in the same sorghum densities (Table 7(a)). The effect of water stress on plant growth as well as 
Table 7. (a) Means of the yield and yield components of sorghum under different irrigation intervals and plant densities as well as their interaction in 2011 and 2012 seasons; (b) Means of the yield and yield components parameters of sorghum under different irrigation intervals and plant densities as well as their interaction in 2011 and 2012 seasons.

(a)

\begin{tabular}{|c|c|c|c|c|c|c|c|c|c|c|c|c|c|}
\hline \multirow[b]{2}{*}{$\begin{array}{l}\text { Irrigation } \\
\text { intervals }\end{array}$} & \multirow[b]{2}{*}{$\begin{array}{c}\text { Plant } \\
\text { density } \\
\mathrm{M}^{2}\end{array}$} & \multicolumn{6}{|c|}{2011 season } & \multicolumn{6}{|c|}{2012 Season } \\
\hline & & $\begin{array}{l}\text { Panicle } \\
\text { length } \\
\mathrm{cm}\end{array}$ & $\begin{array}{c}\text { Panicle } \\
\text { weight } \\
\text { gm }\end{array}$ & $\begin{array}{l}\text { Grain } \\
\text { weight/ } \\
\text { panicle } \\
\text { gm }\end{array}$ & $\begin{array}{c}1000 \\
\text { grain } \\
\text { weight } \\
\text { gm }\end{array}$ & $\begin{array}{l}\text { No. Of } \\
\text { grains } \\
\text { per } \\
\text { panicle }\end{array}$ & $\begin{array}{c}\text { W U E } \\
\mathrm{Kg} / \mathrm{M}^{3} / \mathrm{H} \\
\mathrm{a}\end{array}$ & $\begin{array}{c}\text { Panicle } \\
\text { length } \\
\text { cm }\end{array}$ & $\begin{array}{c}\text { Panicle } \\
\text { weight } \\
\text { gm }\end{array}$ & $\begin{array}{c}\text { Grain } \\
\text { weight/ } \\
\text { panicle, gm }\end{array}$ & $\begin{array}{c}1000 \\
\text { Grain } \\
\text { weight, } \\
\text { gm }\end{array}$ & $\begin{array}{c}\text { No. Of } \\
\text { Grains } \\
\text { per } \\
\text { panicle }\end{array}$ & $\begin{array}{c}\text { WUE } \\
\mathrm{Kg} / \mathrm{M}^{3} / \mathrm{Ha}\end{array}$ \\
\hline \multirow{3}{*}{6} & 6 & 22.2 & 120.9 & 103.7 & 35.5 & 310.4 & 0.336 & 23.3 & 117.9 & 109.3 & 36.7 & 305.4 & 0.356 \\
\hline & 8 & 20.3 & 102.8 & 80.6 & 33.2 & 240.9 & 0.344 & 20.8 & 91.1 & 93.6 & 34.8 & 250.8 & 0.365 \\
\hline & 10 & 18.9 & 87.9 & 66.7 & 31.5 & 204.7 & 0.391 & 18.7 & 88.9 & 67.5 & 33.2 & 200.5 & 0.378 \\
\hline \multicolumn{2}{|c|}{ General mean } & 20.47 & 103.87 & 83.67 & 33.40 & 252.0 & 0.357 & 20.93 & 99.3 & 90.13 & 34.9 & 252.23 & 0.366 \\
\hline \multirow{3}{*}{9} & 6 & 20.0 & 89.8 & 68.5 & 33.4 & 209.8 & 0.437 & 20.3 & 91.8 & 78.8 & 34.5 & 222.4 & 0.451 \\
\hline & 8 & 17.8 & 92.4 & 65.4 & 31.2 & 200.7 & 0.449 & 18.2 & 96.1 & 74.7 & 32.4 & 210.9 & 0.463 \\
\hline & 10 & 17.0 & 82.7 & 61.5 & 30.1 & 200.0 & 0.471 & 17.5 & 86.4 & 64.5 & 31.7 & 204.0 & 0.477 \\
\hline \multicolumn{2}{|c|}{ General mean } & 18.27 & 88.30 & 65.13 & 31.57 & 203.5 & 0.452 & 18.67 & 91.43 & 72.67 & 32.87 & 212.43 & 0.464 \\
\hline \multirow{3}{*}{12} & 6 & 18.7 & 86.5 & 59.3 & 30.2 & 190.8 & 0.520 & 17.9 & 87.6 & 55.4 & 31.4 & 177.0 & 0.544 \\
\hline & 8 & 18.0 & 82.4 & 56.2 & 29.4 & 191.6 & 0.520 & 17.2 & 84.3 & 58.7 & 30.2 & 190.8 & 0.568 \\
\hline & 10 & 17.2 & 76.8 & 54.6 & 28.5 & 188.7 & 0.568 & 17.0 & 80.7 & 56.5 & 30.3 & 180.6 & 0.588 \\
\hline \multicolumn{2}{|c|}{ General mean } & 17.97 & 81.90 & 56.70 & 29.37 & 190.37 & 0.536 & 17.37 & 84.2 & 56.87 & 30.63 & 182.80 & 0.567 \\
\hline \multirow{3}{*}{$\begin{array}{c}\text { General } \\
\text { mean of } \\
\text { factor (B) }\end{array}$} & 6 & 20.3 & 99.07 & 77.17 & 33.03 & 237.0 & 0.431 & 20.5 & 99.10 & 81.17 & 34.20 & 234.93 & 0.450 \\
\hline & 8 & 18.7 & 92.53 & 67.40 & 31.27 & 211.1 & 0.438 & 18.7 & 90.58 & 75.67 & 32.47 & 217.50 & 0.465 \\
\hline & 10 & 17.7 & 82.47 & 60.93 & 30.03 & 197.8 & 0.477 & 17.7 & 85.33 & 62.83 & 31.73 & 195.03 & 0.481 \\
\hline \multirow{3}{*}{ LSD } & A & 1.0 & 4.8 & 8.3 & 1.3 & 18.2 & --- & 1.1 & 5.2 & 14.2 & 1.8 & 20.4 & --- \\
\hline & B & 0.82 & 6.2 & 5.4 & 0.94 & 10.3 & --- & 0.89 & 3.6 & 11.6 & 0.66 & 14.8 & --- \\
\hline & $\mathrm{A} \times \mathrm{B}$ & 0.94 & 7.5 & 1.8 & 1.2 & 12.4 & ---- & 0.70 & 4.2 & 8.5 & 1.2 & 10.7 & --- \\
\hline
\end{tabular}

(b)

\begin{tabular}{|c|c|c|c|c|c|c|c|c|c|}
\hline \multirow[b]{2}{*}{$\begin{array}{l}\text { Irrigation } \quad \mathrm{I} \\
\text { intervals }\end{array}$} & \multirow[b]{2}{*}{$\begin{array}{l}\text { Plant density } \\
\mathrm{m}^{2}\end{array}$} & \multicolumn{4}{|c|}{2011 season } & \multicolumn{4}{|c|}{2012 season } \\
\hline & & $\begin{array}{l}\text { Grain yield } \\
\left(\mathrm{g} / \mathrm{m}^{2}\right)\end{array}$ & $\begin{array}{c}\text { Biological } \\
\text { yield } \\
\left(\mathrm{g} / \mathrm{m}^{2}\right)\end{array}$ & $\begin{array}{l}\mathrm{HI} \\
\%\end{array}$ & $\begin{array}{l}\text { CI } \\
\%\end{array}$ & $\begin{array}{l}\text { Grain yield, } \\
\left(\mathrm{g} / \mathrm{m}^{2}\right)\end{array}$ & $\begin{array}{c}\text { Biological } \\
\text { yield } \\
\left(\mathrm{g} / \mathrm{m}^{2}\right)\end{array}$ & $\begin{array}{l}\mathrm{HI} \\
\%\end{array}$ & $\begin{array}{l}\text { CI } \\
\%\end{array}$ \\
\hline \multirow{3}{*}{6} & 6 & 336 & 1132.3 & 0.30 & 0.42 & 356 & 1166.4 & 0.30 & 0.44 \\
\hline & 8 & 344 & 1143.9 & 0.30 & 0.43 & 364 & 1210.5 & 0.30 & 0.43 \\
\hline & 10 & 391 & 1338.0 & 0.29 & 0.41 & 378 & 1293.0 & 0.29 & 0.41 \\
\hline \multicolumn{2}{|c|}{ General mean } & 357.0 & 1204.7 & 0.30 & 0.42 & 366.0 & 1223.3 & 0.30 & 0.43 \\
\hline \multirow{3}{*}{9} & 6 & 306 & 891.6 & 0.52 & 0.52 & 316 & 899.2 & 0.45 & 0.54 \\
\hline & 8 & 314 & 800.0 & 0.39 & 0.65 & 324 & 857.4 & 0.38 & 0.61 \\
\hline & 10 & 330.0 & 905.5 & 0.36 & 0.57 & 334 & 976.5 & 0.34 & 0.52 \\
\hline \multicolumn{2}{|c|}{ General mean } & 316.7 & 865.7 & 0.40 & 0.58 & 324.7 & 844.4 & 0.39 & 0.56 \\
\hline \multirow{3}{*}{12} & 6 & 260 & 504.3 & 0.51 & 1.06 & 272 & 577.3 & 0.47 & 0.89 \\
\hline & 8 & 260 & 514.9 & 0.51 & 1.02 & 284 & 566.9 & 0.50 & 1.00 \\
\hline & 10 & 284 & 624.4 & 0.45 & 0.83 & 274 & 603.4 & 0.45 & 0.83 \\
\hline \multicolumn{2}{|c|}{ General mean } & 268.0 & 547.9 & 0.49 & 0.96 & 283.3 & 582.5 & 0.47 & 0.91 \\
\hline \multirow{3}{*}{$\begin{array}{l}\text { General mean } \\
\text { of factor (B) }\end{array}$} & 6 & 300.7 & 769.4 & 0.42 & 0.64 & 314.7 & 814.3 & 0.41 & 0.62 \\
\hline & 8 & 306.0 & 819.6 & 0.40 & 0.60 & 324.0 & 878.3 & 0.39 & 0.68 \\
\hline & 10 & 335.0 & 956.0 & 0.37 & 0.54 & 335.3 & 957.6 & 0.36 & 0.59 \\
\hline \multirow{3}{*}{ LSD } & A & 22.4 & 45.20 & --- & --- & 32.8 & 87.9 & --- & --- \\
\hline & B & 18.3 & 40.89 & --- & --- & 8.7 & 42.8 & --- & --- \\
\hline & $A \times B$ & 21.0 & 12.60 & --- & --- & 9.6 & 62.4 & --- & --- \\
\hline
\end{tabular}


final yield and yield component characters of sorghum were investigated by some researchers, they concluded that, identification the optimum time of water supplies can reach to the optimal yield performance. Compatible results were obtained by [10] and [11]. The analysis of the yield component parameters presented in (Table 7(a)) indicated that the reduction in panicle length, and panicle weight, grain weight per panicle, 1000 grain weight and number of grains per panicle is associated with increasing in plant densities. Contrary grain yield per hectare is partly compensated by an increase in plant density (Table 7(a)). Thus, the highest plant density registered the highest grain yield $335.0 \mathrm{~g} / \mathrm{m}^{2}$ as compared to low plant density $300.7 \mathrm{~g} / \mathrm{m}^{2}$. These results are similar to those found by [12] [18] and [19], however, other authors did not found yield compensation processes in other cereals for different plant populations [38]. Significant differences were also found in the interactions between the different irrigation treatments and plant densities, since the higher number of plants per $\mathrm{m}^{2}\left(10\right.$ plants per $\left.\mathrm{m}^{2}\right)$ and application irrigation water every 6 days were followed. The data of the two years presented in (Table 7(b)) indicated that a high plant density under deficit irrigation conditions did not present any advantage in the sorghum yield. Such effect may be attributed to the fact that, plants grown under more moisture content in root zone, photosynthesis rate and photosynthetic substrates translocation is expected to be high compared to plants under stress condition and consequently seed yield of these plants are also expected to have less.

\subsection{Effect on Chemical Composition of Leaves and Grains}

Proline content reduced under moderate water stress, but increased under severe water stress (Table 8). In agreement with our results, [39] reported an increase in proline content of several plant species in water stress conditions. They further suggested that the accumulation of proline may play an important role in drought adaptation in the tested species. It is also clear from (Table 8) that, increasing plant density increased leaf proline content. Thus, the highest number of plants per $\mathrm{m}^{2}\left(10\right.$ plants $\left./ \mathrm{m}^{2}\right)$ registered the highest values of leaf proline content 3.27 and $3.36(\mu \mathrm{mol} / \mathrm{g} \mathrm{FW})$ in the first and second seasons, respectively. Furthermore, the interactions of both factors recorded significant differences, sowing sorghum by the highest number of plants per $\mathrm{m}^{2}$ under low

Table 8. Grain quality parameters of Sorghum under different irrigation intervals and plant densities as well as their interaction in 2011 and 2012 seasons.

\begin{tabular}{|c|c|c|c|c|c|c|c|}
\hline \multirow[b]{2}{*}{$\begin{array}{l}\text { Irrigation } \\
\text { intervals }\end{array}$} & \multirow[b]{2}{*}{$\begin{array}{l}\text { Plant density } \\
\mathrm{m}^{2}\end{array}$} & \multicolumn{3}{|c|}{2011 season } & \multicolumn{3}{|c|}{2012 season } \\
\hline & & $\begin{array}{c}\text { Leaves proline } \\
\text { content } \\
(\mu \mathrm{mol} / \mathrm{g} \mathrm{FW})\end{array}$ & $\begin{array}{c}\text { Crude protein } \\
\%\end{array}$ & $\begin{array}{c}\text { Total } \\
\text { carbohydrate \% }\end{array}$ & $\begin{array}{c}\text { Leaves proline } \\
\text { content } \\
(\mu \mathrm{mol} / \mathrm{g} \mathrm{FW})\end{array}$ & $\begin{array}{c}\text { Crude protein } \\
\%\end{array}$ & $\begin{array}{c}\text { Total } \\
\text { carbohydrate \% }\end{array}$ \\
\hline \multirow{3}{*}{6} & 6 & 2.38 & 10.26 & 84.55 & 2.72 & 12.46 & 82.65 \\
\hline & 8 & 2.78 & 9.12 & 83.52 & 2.82 & 10.25 & 82.12 \\
\hline & 10 & 3.00 & 8.22 & 83.22 & 2.89 & 9.72 & 81.42 \\
\hline \multicolumn{2}{|c|}{ General mean } & 2.72 & 9.20 & 83.76 & 2.81 & 10.81 & 82.06 \\
\hline \multirow{3}{*}{9} & 6 & 3.10 & 9.82 & 83.00 & 3.57 & 10.22 & 81.21 \\
\hline & 8 & 3.24 & 8.62 & 82.69 & 3.30 & $9 . .32$ & 81.00 \\
\hline & 10 & 3.28 & 8.10 & 82.42 & 3.34 & 8.00 & 80.45 \\
\hline \multicolumn{2}{|c|}{ General mean } & 3.21 & 8.85 & 82.70 & 3.40 & 9.18 & 80.89 \\
\hline \multirow{3}{*}{12} & 6 & 3.00 & 8.24 & 82.32 & 3.38 & 9.44 & 80.12 \\
\hline & 8 & 3.33 & 7.65 & 82.00 & 3.42 & 8.12 & 80.00 \\
\hline & 10 & 3.52 & 7.23 & 82.00 & 3.86 & 8.00 & 80.00 \\
\hline \multicolumn{2}{|c|}{ General mean } & 3.28 & 7.71 & 82.11 & 3.55 & 8.52 & 80.04 \\
\hline \multirow{3}{*}{$\begin{array}{l}\text { General mean of } \\
\text { factor }(\mathrm{B})\end{array}$} & 6 & 2.83 & 9.44 & 83.29 & 3.22 & 10.71 & 81.33 \\
\hline & 8 & 3.12 & 8.46 & 82.74 & 3.18 & 9.23 & 81.04 \\
\hline & 10 & 3.27 & 7.85 & 82.55 & 3.36 & 8.57 & 80.62 \\
\hline \multirow{3}{*}{ LSD } & A & 0.36 & ---- & --- & 0.54 & ---- & ---- \\
\hline & $\mathrm{B}$ & 0.28 & ---- & ---- & 0.12 & ---- & ---- \\
\hline & $A \times B$ & 0.21 & ---- & ---- & 0.34 & ---- & ---- \\
\hline
\end{tabular}


moisture content in root zone recorded the highest values of leaf proline content. Such effect may be attributed to high competition between plants for water and dissolving nutrients and low photosynthetic substrates translocation. From the data in the same (Table 8), it could be recognized that the highest crude protein and carbohydrate content were recorded under the watered irrigation treatment (irrigation every 6 days), after that a gradual decrease was noticed as water deficit was increased. In addition, carbohydrate content seems to be more stable with slight changes compared to crude protein in both seasons.

The effect of different plant densities on leaves proline content and grains chemical composition, data obtained reveal that increasing number of plants per square meter decreased either leaves proline content or grains chemical composition, whereas carbohydrate content did not gave a stable or defined trend on both seasons. The interaction effect in (Table 8), clearly show that increasing plant densities under high level of water deficit, mostly increased leaves proline content and in the same times decreased grains chemical composition.

\section{Conclusions}

Decreasing water supply by increasing the time between irrigations produced a significant reduction of the aerial sorghum characters viz., stem diameter, number of green leaves per plant, time required to reach to $50 \%$ flowering, plant height, leaf area per plant and all of these parameters put in a reduction in the grain yield. The most important parameter among yield component parameters under investigation is harvest index, which is increased as water stress increased. Such results indicated that grain yield was more sensitive to water stress than the aerial dry matter production. For the three plant densities, the relationship between grain yield and harvest index was similar under the three water irrigation applied.

The results indicated that important compensation processes occurred between the different sorghum yields components. Thus, the lesser number of plants per $\mathrm{m}^{2}$ of the lower sorghum densities were compensated with a greater production of tillers, a greater number of grains per panicle and a higher weight of these grains. The result of this study suggests that sowing sorghum using less density could be an alternative crop if water supply is limiting under water deficit conditions.

\section{Acknowledgements}

The authors would like to extend their sincere appreciation to the Deanship of Scientific Research at King Saud University for financially supporting this work.

\section{References}

[1] FAO (2003) (Food and Agriculture Organization), FAO Yearbook: Production. Vol. 55, FAO, Rome, 164-166.

[2] Borlaug, N.E. and Dowswell, C.R. (2005) Feeding a World of Ten Billion People: A 21st Century Challenge. In: Tuberosa, R., Phillips, R.L. and Gale, M., Eds., Proceedings of the International Congress in the Wake of the Double Helix: From the Green Revolution to the Gene Revolution, Bologna, 27-31 May 2003, 3-23.

[3] Komeili, H.R., Rashed-Mohassel, M.H., Ghodsi, M. and Zare-FeizAbadi, A. (2008) Evaluation of Modern Wheat Genotypes in Drought Resistance Condition. Agricultural Researches, 4, 301-312.

[4] Zhang, S.O. and Outlaw Jr., W.H. (2001) Abscisic Acid Introduced into Transpiration Stream Accumulates in the Guard Cell Apoplast and Causes Stomatal Closure. Plant, Cell \& Environment, 24, 1045-1054. http://dx.doi.org/10.1046/j.1365-3040.2001.00755.x

[5] Banon, S., Fernandez, J.A., Franco, J.A., Torrecilas, A., Alarcon, J.J. and Sanchez-Blanco, M.J. (2004) Effects of Water Stress and Night Temperature Preconditioning on Water Relation and Anatomical Change of Lotus creticus Plants. Science Horticulture, 101, 333-342. http://dx.doi.org/10.1016/j.scienta.2003.11.007

[6] Igartua, E., Gracia, M.P. and Lasa, J.M. (1994) Characterization and Genetic Control of Germination-Emergence Responses of Grain Sorghum to Salinity. Euphytica, 76, 185-193. http://dx.doi.org/10.1007/BF00022163

[7] Kole, C. (2001) Wild Crop Relatives: Genomic and Breeding Resource Cereals. Institute of Natural Research.

[8] Agrama, H.A. and Tuinstra, M.R. (2003) Phylogenetic Diversity and Relationships among Sorghum Accessions Using SSRs and PAPDs. African Journal of Biotechnology, 2, 334-340. http://dx.doi.org/10.5897/AJB2003.000-1069

[9] Buah, S.S.J. and Mwinkaara, S. (2009) Response of Sorghum to Nitrogen Fertilizer and Plant Density in the Guinasavana Zone. Agronomy Journal, 8, 124-130. http://dx.doi.org/10.3923/ja.2009.124.130

[10] Hosseinian Maleki, S. and Mirshekari, B. (2011) Irrigation Period in Three Rapeseed Cultivars Influences Crop Phe- 
nology and Yield. Journal of Food, Agriculture and Environment, 9, 446-448.

[11] Gohari, A.A. (2012) Effect of Soil Water on Plant Height and Root Depth and Some Agronomic Traits in Common Bean (Phaseolus vulgaris) under Biological Phosphorous Fertilizer and Irrigation Management. International Research Journal of Applied and Basic Sciences, 3, 848-853.

[12] Ma, B.L., Dwyer, L.M. and Costa, C. (2003) Row Spacing and Fertilizer Nitrogen Effects on Plant Growth and Grain Yield of Maize. Canadian Journal of Plant Science, 83, 241-247.

[13] Selim, M.M. (1995) Evaluation of Some Grain Sorghum Genotypes Grown under Different Plant Densities and Levels of Nitrogen Fertilization. Egyptian Journal of Agronomy, 20, 83-97.

[14] Fischer, K.S. and Wilson, G.L. (1975) Studies of Grain Production in Sorghum bicolor (L. Moench).V. Effect of Planting Density on Growth and Yield. Australian Journal of Agricultural Research, 26, 31-41. http://dx.doi.org/10.1071/AR9750031

[15] Ferraris, R. and Charles-Edwards, D.A. (1986) A Comparative Analysis of the Growth of Sweet and Forage Sorghum Crop. I. Dry Matter Production, Phenology and Morphology. Australian Journal of Agricultural Research, 37, 495512.

[16] Berenguer, M.J. and Faci, J.M. (2001) Sorghum (Sorghum bicolor L. Moench) Yield Compensation Processes under Different Plant Densities and Variable Water Supply. European Journal of Agronomy, 15, 43-55. http://dx.doi.org/10.1016/S1161-0301(01)00095-8

[17] Borrás, L., Maddonni, G.A. and Otego, M.E. (2003) Leaf Senescence in Maize Hybrids: Plant Population, Row Spacing and Kernel Set Effects. Field Crops Research, 82, 13-26. http://dx.doi.org/10.1016/S0378-4290(03)00002-9

[18] Charles, A.S. and Charles, S.W. (2006) Corn Response to Nitrogen Rate, Row Spacing, and Plant Density in Eastern Nebraska. Agronomy Journal, 94, 529-535.

[19] Zand, N., Shakiba, M.-R., Moghaddam-Vahed, M. and Dabbagh-Mohammadai-nasab, A. (2014) Response of Sorghum to Nitrogen Fertilizer at Different Plant Densities. International Journal of Farming and Allied Sciences, 3, 71-74.

[20] Cottenie, A., Verlo, M., Kjekens, L. and Camerlynch, R. (1982) Chemical Analysis of Plant and Soil. Laboratory of Analytical Agrochemistry. State University, Gent, Belgium, Article No. 42, 80-284.

[21] But, R. (2004) Soil Survey Laboratory Manual Report No. 42 USDA. National Resources Conservation Service, Washington DC.

[22] American Public Health Association (APHA) (1992) Standard Methods for Examination of Water and Wastewater. 18th Edition, APHA, AWWA, WPCF, NY, Washington DC.

[23] Bos, M.G. (1985) Summary of ICID Definition of Irrigation Efficiency. ICID Bulletin, 34, 28-31.

[24] Donald, C.M. and Hamblin, J. (1976) The Biological Yield and Harvest Index of Cereals as Agronomic and Plant Breeding Criteria. Advances in Agronomy, 28, 361-405. http://dx.doi.org/10.1016/S0065-2113(08)60559-3

[25] Bates, L.S., Waldren, E.P. and Teare, I.D. (1973) Rapid Determination of Free Proline for Water Stress Studies. Plant and Soil, 39, 205-207. http://dx.doi.org/10.1007/BF00018060

[26] AOAC (2000) Official Methods of Analysis. 25th Edition, Association of Official Analysis Chemists, Washington DC.

[27] Dubois, M., Gilles, K.A., Hamilton, J., Roberts, R. and Smith, F. (1956) Colorimetric Method for Determination of Sugar and Related Substances. Analytical Chemistry, 28, 350-356. http://dx.doi.org/10.1021/ac60111a017

[28] Gomez, K.A. and Gomez, A. (1984) Statistical Procedure for Agricultural Research—Hand Book. John Wiley \& Sons, New York.

[29] Sadeghipour, O. (2009) The Influence of Water Stress on Biomass and Harvest Index in Three Mung Bean Cultivars. Asian Journal of Plant Sciences, 8, 245-249. http://dx.doi.org/10.3923/ajps.2009.245.249

[30] Shiri, M., Momeni, H. and Geranmayeh, B. (2013) The Survey of the Morphological and Physiological Basis of Maize Grain Yield under Drought Stress Condition through Path Analysis. Technical Journal of Engineering and Applied Sciences, 3, 3647-3651.

[31] Krieg, D.R. and Lascano, R.J. (1990) Sorghum. In: Stewart, B.A. and Nielsen, D.R., Eds., Irrigation of Agricultural Crops, American Society of Agronomy, Madison, 719-740.

[32] Tyagi, A.P., Mor, B.R. and Singh, D.P. (1998) Path Analyses in Upland Cotton (G. hirsutum L.). The Indian Journal of Agricultural Science, 22, 137-142.

[33] Hussein, M.M. and Alva, A.K. (2014) Growth, Yield and Water Use Efficiency of Forage Sorghum as Affected by NPK Fertilizer and Deficit Irrigation. American Journal of Plant Sciences, 5, 2134-2140. http://dx.doi.org/10.4236/ajps.2014.513225

[34] Ismail, A.M.A. and Ali, A.H. (1996) Effect of Nitrogen Rates and Plant Densities on Some Morphological Characters 
and Yield of Grain sorghum. Arab Gulf Journal of Scientific Research, 4, 49-58.

[35] Swamya, B.P.M., Upadhyaya, H.D., Goudara, P.V.K., Kullaiswamya, B.Y. and Singh, S. (1997) Phenotypic Variation for Agronomic Characteristics in a Groundnut Core Collection for Asia. Field Crops Research, 84, 359-370. http://dx.doi.org/10.1016/S0378-4290(03)00102-3

[36] Abuzar, M.R., Sadozai, G.U., Baloch, M.S., Baloch, A.A., Shah, I.H., Javaid, T. and Hussain, N. (2011) Effect of Plant Population Densities on Yield of Maize. Journal of Animal and Plant Sciences, 21, 962-965.

[37] Zamir, M.S.I., Ahmad, A.H., Javeed, H.M.R. and Latif, T. (2011) Growth and Yield Behaviour of Two Maize Hybrids (Zea mays L.) towards Different Plant Spacing. Cercetari Agronomice in Moldova, 44, 33-40. http://dx.doi.org/10.2478/v10298-012-0030-9

[38] Guberac, V., Martincic, J., Maric, S., Bede, M., Jurisic, M. and Rozman, V. (2000) Grain Yield Components of Winter Wheat New Cultivars in Correlation with Sowing Rate. Cereal Research Communication, 28, 307-314.

[39] Wang, S., Wan, C., Wang, Y., Chen, H., Zhou, Z., Fu, H. and Sosebee, R.E. (2004) The Characteristics of $\mathrm{Na}^{+}$, K ${ }^{+}$and Free Proline Distribution in Several Drought-Resistant Plants of the Alxa Desert, China. Journal of Arid Environments, 56, 525-539. http://dx.doi.org/10.1016/S0140-1963(03)00063-6 